ETO: 821.511.141-31OTTLIK G.

821.511.141-31KERTÉSZ I.

DOI: $10.19090 / \mathrm{hk} .2019 .3 .57-78$

ORIGINAL SCIENTIFIC PAPER

\author{
BARCSI Tamás \\ Pécsi Tudományegyetem, Állam- és Jogtudományi Kar \\ Jogbölcseleti és Társadalomelméleti Tanszék \\ Pécs, Magyarország \\ barcsi48@gmail.com
}

\title{
A FELÜGYELETI REND IRODALMI REPREZENTÁCIÓI OTTLIK GÉZA ÉS KERTÉSZ IMRE REGÉNYEIBEN
}

\section{Literary Representations of Supervisory Order in Ottlik Géza and Imre Kertész’s Novels}

\section{Književni prikaz nadzorne vlasti u romanima Geze Otlika i Imrea Kertesa}

A dolgozat a szerző Bevezetés a kegyetlenség világába: Civilizáció, felügyeleti hatalom és kegyetlenség Ottlik Géza müveiben címü, filozófiai, etikai, szociológiai szempontú tanulmányának folytatásaként ${ }^{1}$ áttekinti az Iskola a határon című regényben fellelhető lázadási módokat, valamint bemutatja, hogy miként függ össze Ottlik Géza regényeinek világában az emberi rend és a világrend. Összeveti Ottlik főmüvét Kertész Imre Sorstalanságával, és rámutat arra, milyen párhuzamok tárhatók fel a kegyetlenné vált felügyeleti rend és a koncentrációs tábor, illetve ezek egy-egy irodalmi reprezentációja között.

Kulcsszavak: felügyelet, civilizáció, lázadás, iskola, koncentrációs tábor

\section{Az ellenszegülés változatai az Iskola a határon-ban}

A kegyetlenség rendjévé váló iskolában történnek olyan események, amelyek felmutatják, hogy amit itt nem tekintenek természetesnek, az természetes (a civil világ erkölcsi normái érvényesek, még akkor is, ha mindenki úgy tesz, mintha nem lennének azok), és fordítva: amit természetesnek tekintenek (az

\footnotetext{
${ }^{1}$ Lásd Barcsi 2019.
} 
alapvető erkölcsi normák figyelmen kívül hagyása), az valójában nem természetes. A lázadó növendékek különböző módon, de megkérdőjelezik az iskola rendjét. Nézzük meg röviden, hogy a tiltakozásnak, ellenszegülésnek milyen változatai jelennek meg a regényben. A lázadás szó a 3. alpontban idézőjelben szerepel, mert Apagyi és Tóth Tibor ellenszegülése más-más okokból, de nem az adott rend nem-természetes voltának tudatos belátásából fakad.

\section{Öttevényi lázadása}

Öttevényi Merényi terror-uralmával szegül szembe, Merényiék „,megszokott erőszakoskodására"² szokatlanul reagál: feliratkozik panaszra, tehát a hivatalos hierarchiához fordul, pedig az altisztek és a tisztek nem csinálnak titkot abból, hogy „minden panasz alaptalannak fog minősülni” (Ottlik 1995, 171). Végül egy koncepciós eljárásban Öttevényit találják bünösnek, elbocsátják, és egy évre kicsapják minden középiskolából. Még az eljárás előtt Öttevényit társai kiközösitik, a vezető klikk megalázza, és Merényi a többiek előtt megveri. Öttevényi a „civil világ” természetes erkölcsi normáinak megfelelően cselekszik, amikor kiáll Jaksért, a barátjáért, és nem hagyja annyiban a vele szemben elkövetett igazságtalanságot, ugyanakkor azt is tudnia kell, hogy tettének súlyos következményei lesznek, mert senki sem fog mellé állni. Ez valóban így is történik, még Jaks is ellene vall. ${ }^{3}$ Az igazságtalanságokat nem orvosolja senki, sőt, még további, durva igazságtalanságok tetézik a korábbiakat. A rend mechanizmusai a „civil erkölcsök” érvényességét felmutatni próbáló növendéket bélyegzik erkölcstelennek, egyértelmüvé téve, hogy az iskolában a civil erkölcsnek nincs helye. Az, hogy Öttevényit „nem sajnálják” a növendékek, és még a jobb érzésủek is (mint a történetet elbeszélő Bébé) „gyáva árulónak”, „férfiatlan” alaknak tartják (Ottlik 1995, 182), a tagadás, illetve az ellentétbe fordítás elháritó mechanizmusai müködéseként értelmezhetők. További iskolai életüket nehezítené meg, ha szembenéznének azzal, hogy valójában ök voltak az erkölcstelenek, a gyáva árulók és Öttevényi volt az, aki bátorságról, férfiasságról, erkölcsi tartásról tett tanúbizonyságot. Ugyanakkor számos jele van annak, hogy a növendékek, Merényiék klikkjének kivételével, érzik - bárhogy próbálnak védekezni ez ellen -, hogy az iskolában nem-természetesnek minősített

2 „Merényiék megszokott módon erőszakoskodtak” (Ottlik 1995, 170). Elveszik többek között Öttevényi füzetét és barátja, Jaks ceruzáját.

${ }^{3}$ Jaks érdekei felülírják a barátságot: árva gyerekként nem kockáztathatja, hogy kirúgják az iskolából, ahol államköltségen tanulhat. 
magatartás a természetes. Erre utal a hamis vallomást tévő Drágh dühe (a kihallgatása után „fojtott indulattal” azt válaszolja az őt kérdőre vonó Öttevényinek, hogy az igazságot mondta, mert nem szokott hazudni, Ottlik 1995, 178), Jaks némasága („örökre szúkszavú maradt”, Ottlik 1995, 179), vagy az, hogy rossz érzés nézniük a csomagoló Öttevényit. ${ }^{4}$

\section{Medve lázadása}

Amikor az 1923 őszén másodévesként bevonuló újoncoknak derengeni kezd, hogy egy olyan világba kerültek, ami az általuk korábban megszokottaktól mindenben eltér, próbálnak alkalmazkodni. Ez Czakónak sikerül legelőször, Bébé „,szakadatlan szükölésből és görcsös figyelemböl” áll, hogy megértse, mivé is kell válnia, az elvárásokat Medve érti meg a „leglassabban és legnehezebben" (Ottlik 1995, 62). Ugyanakkor Medve akkor is lázad, amikor már átlátja az iskola rendjének müködésmódját, mert elfogadhatatlannak tartja, hogy egy ilyen rendbe kritikátlanul betagozódjon. Medve a kéziratában saját gyávaságát hangsúlyozza, Bébé azonban ,eszeveszetten bátor fiúnak” nevezi (Ottlik 1995, 88). Medve idegessége és az ebből adódó ügyetlensége (parancsra képtelen megismételni azt a tornagyakorlatot, amit korábban játszva teljesített, Ottlik 1995, 90) mutatja, hogy lelki ellenállása olyan erős, hogy testi „tüneteket” is produkál. Medve nem hajlandó természetesnek tekinteni az igazságtalanságokat, újoncként (a „pokrócozása” után is) többször szembeszáll Merényiékkel", de az iskola hivatalos rendjét sem fogadja el: a csuklógyakorlatokat csak akkor

\footnotetext{
${ }^{4}$ Merényi az eljárás lezárulásával felcipeli a dobogóra a már kicsapott, veréstől bedagadt szájú, megalázott fiút, hogy mindenki lássa, mi a sorsa az „árulóknak”, azaz a vele szembeszegülőknek: a megkínzott Öttevényi „dacos, duzzadt” arccal áll a dobogón (Ottlik 1995, 182). A Továbbélőkben Ottlik azt hangsúlyozza, hogy Öttevényi alapvető célja az iskola elhagyása: „Öttevényi azonban önszántából látszott kilépni az egész rendszerből” (Ottlik 1999, 105). Öttevényit „árulása” után ebben a változatban nem bántalmazzák, egyszerủen idegenként tekintenek rá. A Továbbélőkben nincs akkora súlya az Öttevényi-ügynek, mint az Iskolában, amelyben az aktív szembehelyezkedés értelmetlenségének szimbólumaként tekintenek rá a növendékek több éven keresztül.

${ }^{5}$ Medve a második héten nekimegy a provokátor Varjúnak (amiért összeverik); ráförmed Bébére, amiért önként Szabó Gerzsonnak adja a csomagolópapírját, hogy megnyerje a rokonszenvét; Bébét védelmébe veszi az árnyékszéken, amikor a többiek froclizzák; levelet juttat el az anyjának, aki el is jön (de Medve képtelen neki elmondani, hogy mit él át, azt várná, hogy az anyja szavak nélkül is megértse); az egyik igazságtalan eljárás ellen tiltakozva a földhöz vágja a „zsírtalan zsíros kenyerét” (amiért fogdát kap). Vö. Ottlik 1995, 104, 111, 114, 118-120, 142-146, 191-193, 237.
} 
csinálja pontosan, amikor a ködben senki nem látja (Ottlik 1995, 216). Medve a renddel szembeni aktív ellenállás értelmetlenségére ráébredve dolgozza ki szökési tervét: a megváltoztathatatlannak tünő és elviselhetetlen rendet el kell hagyni. Szökni nem ugyanaz, mintha Medvét az anyja hazavinné: ez vereség lenne, a sikeres szökés azonban az egyik legfőbb engedetlenség megvalósítása, így a rend felett aratott valamiféle diadalként is felfogható. Medve megszökik, de visszafordul, feltehetően azért, mert ráébred arra, hogy az iskolában szerzett tapasztalataival már nem lenne képes a régi életét - az ,ártatlan” gyerekkort ott folytatni, ahol abbahagyta. Elképzelhető, hogy azért gondolja meg magát, mert a szökés mégiscsak megfutamodás a „sorsa” elöl - akkor indul el visszafelé, amikor eszébe jut a hálóterem, a fiúk arca, és egyértelmúvé válik előtte, hogy bármennyire is nem akarja, már közéjük tartozik -, ha elmenekül, beismeri gyávaságát, azt, hogy képtelen helytállni (Ottlik 1995, 204-207). ${ }^{6}$ Míg a Továbbélőkben Szebek a szökése után beilleszkedik az iskolába, addig Medve későbbi magatartásával is azt fejezi ki, hogy látszólagos alkalmazkodása nem jelenti a rend elfogadását. Ez valamiféle tekintélyt kölcsönöz neki: „Ő volt az egyetlen, akivel olykor még a Varjú is szőrmentén bánt; alig észrevehetően. [...] Medve nem próbált hízelegni nekik, nem mutatott barátságos arcot soha. És a kiszámíthatatlan indulatosságától ha nem is féltek éppen, de óvakodtak valamennyire" (Ottlik 1995, 308). Negyedévesként párbajt vív Homolával, majd Merényivel, ellenfele csak késsel fenyegetve tudja a küzdelem befejezésére kényszeríteni. Medve ugyan letérdel, de érezhetően mégis ő a győztes, az általa okozott sebet viseli az arcán az érinthetetlennek hitt Merényi. A klikk bukása után Medve megakadályozza Tóth Tibor megverését, Bébével együtt csak ,pedagógiai” pofonokat osztanak ki a közösséggel szembehelyezkedő társaiknak. ${ }^{7}$ A Budából kiderül, hogy Medve a sokkal elviselhetőbb föreálban is folytatja lázadását - diákklikk hiányában itt csak a hivatalos rend ellen -, az alsóéves növendékek példaképként tekintenek rá. ${ }^{8}$

\footnotetext{
${ }^{6}$ A Továbbélőkben ezt olvashatjuk arról, hogy miért akar maradni a szökését követően Szebek: „Miután megismerte, nem tudott többé tudomást nem venni erről a világról, nem tudta idegennek érezni a többieket. Dolga van velük. Meg kell érteniük egymást elsősorban” (Ottlik 1999, 84).

${ }^{7}$ Medve azonban a Kappéternek ilyen okból adott pofon miatt is „elszontyolodik” (Ottlik 1995, 346).

${ }^{8}$ „A szökése Zsoldossal, a hat nap magánzárka, a pótvizsga, a féléves megrovás, teljesen rendben volt: hozzátartozott, beleillett az általános szembenállásába, ellenszegülésébe a hazug renddel: tudta mindenki, Lukács, a parancsnokunk is tudta. Ö azt is pontosan tudta, hogy Medve tündöklő példakép az alsóbb éveseknek" (Ottlik, 1993, 329-330).
} 


\section{Apagyi és Tóth Tibor ,lázadása”}

Az elsőéves parasztfiú, Apagyi nem teljesíti a parancsokat, azt teszi, amit éppen jónak gondol, nem tart lépést a többiekkel, az étteremben elmondja az imát, de vigyázzállás nélkül, a vezényszavakra nem reagál, nem fogad szót sem a felsőéveseknek, sem a felnőtteknek, de még az iskola parancsnokával is félvállról beszél. Apagyi folyton vigyorog, viselkedéséből úgy tünik, kissé ütődött, ugyanakkor nem hagyja magát bántani, bicskáját előkapva védekezik a támadások ellen. Apagyi ellenállása nyilvánvalóan nem erkölcsi alapú, az emberi méltóság tiszteletét megkövetelő lázadás (mint Öttevényi és Medve esetében), hanem egy szabadsághoz szokott fiú ösztönös reagálása az értelmetlen kényszerekre. Ahogy a bolond olykor kimondja az igazságot, úgy mutat rá viselkedésével Apagyi - aki az értékalapú lázadóknál is radikálisabb ellenállást tanúsít - az intézmény problematikusságára: az iskolában katonaként kell élnie gyerekeknek, értelmetlenül szigorú szabályok közé szorítva. Apagyi sorsa azt mutatja, hogy nemcsak a kegyetlen növendékek számíthatnak a hivatalos hierarchia elnézésére vagy támogatására, de az iskolának is hasznot hajtanak a kegyetlenkedök tettei, hiszen megbüntetik vagy akár elüldözik a „bünösöket”, tehát a gyengéket és az ellenszegülőket. Ahogy Öttevényi „kivégzésében” a hivatalos hierarchia együttmüködik Merényiékkel, úgy az iskola rendjét figyelmen kívül hagyó Apagyit a tisztek, altisztek beavatkozása nélkül évfolyamtársai - akik újoncok, így akár a „hősük” is lehetne az engedetlen fiú - maguk intézik el, Apagyi elhagyja az iskolát. Ottlik 1948-ban a Válaszban megjelent novellában írta meg elöször az Apagyi-történetet (Ottlik 1994a, 383-388). A Továbbélőkben is fontos szerepet tölt be Öttevényi és Apagyi lázadása, de ebben az Apagyi-eset 1923-as, Öttevényi szembeszegülésére pedig 1926 februárjában kerül sor (Ottlik 1999, 99). Ottlik az Iskolában változtatott az időrenden: talán részben azért, mert Öttevényi esete további indokot szolgáltat Medve szökéséhez, hiszen ennek az a tanulsága, hogy a kegyetlen renddel szembeni aktív fellépés lehetetlen. A helyzetét át nem látó, „bolond” Apagyi eltúlzott, ezért eleve bukásra ítélt engedetlenségének megtorlásából nem feltétlenül következik, hogy az adott rendszerrel, föleg a diákuralommal szembeni fellépés nem lehetséges.

Tóth Tibor Apagyi ellentéte: minden iskolai elöírást tökéletesen teljesíteni akar, de Merényiék klikkjének tevékenységét sem kritizálja, annak ellenére, hogy nyíltan hangoztatja keresztény elveit. Ha froclizni kezdik, rögtön sírva fakad, ezzel eléri, hogy senki nem bántja fizikailag (mivel rögtön és látványosan kimutatja a gyengeségét, nincs semmi élvezet a „kínzásában”), esetleg trágár szavakkal bosszantják. A Tóth Tibor által hirdetett elvek nem mutatkoznak meg a viselkedésében: vallási kötelezettségeit ugyan buzgón teljesíti, naponta jár 
misére, de közel sem a szeretetetika alapján cselekszik, önmagán kívül más nem érdekli. „Tóth Tibor a maga módján még pimaszabb önbizalommal hitt saját nagyszerüségében, mint Merényiék" (Ottlik 1995, 320). A szabályokat is azért akarja minél tökéletesebben betartani, mert ezzel folyton bizonyíthatja önmagának saját kiválóságát, és ilyen okok miatt örömmel csatlakozik Merényiék holdudvarához, amikor erre lehetôsége adódik. ${ }^{9}$ Az Iskolában és a Budában Tóth Tiborral kapcsolatban többek között a következő jelzőket olvashatjuk: ,szenteskedő”, „tartózkodó természetü”, ,,szemtelen”, „,szívós”, „,hideg”, „durva lelkü” (Ottlik 1995, 319, 320-321; Ottlik 1993, 158). Tóth Tibor a legkevésbé sem hősies alkat, mégis ő buktatja meg Merényiéket, amikor beárulja őket Hanák főtisztelendőnek, miután Merényiék kitaszítják őt a köreikből. Ahogy korábban koncepciós eljárásban ítélték el az ártatlan Öttevényit, úgy a korántsem ártatlan Merényiékkel szemben is így járnak el, a növendékek vallomása nem változtatja meg érdemben a Hanák és Tóth Tibor által megfabrikált bünlajstromot, az igazság ekkor is kevéssé számít. ${ }^{10}$ Tóth Tibor nem erkölcsi okokból fordul Merényiék ellen, tettének semmi köze a keresztény etikához: csupán bosszút akart állni az ôt ért sérelem miatt, amely a megszokottakhoz képest egyáltalán nem súlyos, de narcisztikus személyiségével Tóth képtelen belenyugodni új „státuszának” elvesztésébe. ${ }^{11}$ Mindenesetre az, hogy Tóth Tibor megfogadja Varjú tréfának szánt tanácsát és elmegy panaszra a főtisztelendőhöz, nem a sértett Tóth bosszúvágyának erejét, hanem Merényiék tekintélyének gyengülését mutatja elsősorban: Tóth „csak a kegyelemdöfést adta meg egy ingó rendszernek, s elég csúnya, szinte igazságtalan, kegyetlen kegyelemdöfést" (Ottlik 1995, 343). A klikk erejének meggyengüléséhez minden bizonnyal hozzájárultak az évek során velük szemben elkövetett ellenszegülések, Öttevényi tettétől a kis „lázadásokon” át Medve Homolával és Merényivel folytatott párbajáig, hiszen ezek - hiába nyerték el büntetésüket az engedetlenkedők - azt jelezték

${ }^{9}$ Tóth azért fogadja el Medve közeledését - akit vonz a fiú szépsége és lényének idegenszerüsége -, mert ez a közeledés is a nagyszerüségébe vetett hitét erősíti. Amikor a Merényi-klikkhez tartozó Varjú is érdeklődést mutat iránta, megszakítja „barátságát” Medvével (Ottlik 1995, 325-326).

${ }^{10}$ Merényiék legfőbb bünéül azt róják fel, amit el sem követtek („,természetellenes nemi visszaélés", Ottlik 1995 341-342, 344). A klikk tagjait (Varjú kivételével) kicsapják, de a külső körből is elbocsátanak két fiút. Az, hogy a kegyetlen Varjú megússza a büntetést - ő később a növendékek bosszújától tartva magától távozik -, szintén mutatja, hogy az igazság ebben az eljárásban sem sokat számít.

${ }^{11}$ A Továbbélőkben is Tóth Tibor okozza a Merényi-klikk bukását, azonban itt a klikkből már korábban kilépő, de tekintélyét megőrző Gereben Énok az, aki megakadályozza a további kegyetlenkedéseket (Ottlik 1999, 148). Az Iskolában Gereben korántsem ennyire pozitív figura, őt is kicsapják. 
újra és újra, hogy Merényiék hatalma és viselkedése cseppet sem természetes. A kis (sokszor nem is tudatos) „lázadások” kapcsán érdemes utalni a Budára, amelyben Bébé megemlíti: „Medve szerint azzal kezdődött Merényi bukása, hogy (egy szabadkézi rajzórán a föalléban) szórakozottan hanyattlöktem, és pingáltam tovább" (Ottlik 1993, 31).

\section{Emberi rend és világrend}

Medve a szökése miatti büntetését tölti a fogdában, amikor ráébred arra, hogy nincs miért sajnálnia magát, hiszen az ember a belső szabadságát, függetlenségét bármilyen körülmények között megőrizheti (Ottlik 1995, 236). ${ }^{12}$ Kiderül azonban az is, hogy nemcsak lelki értelemben lehet szabad az iskolában a növendék, hanem olykor - bár csak ,pillanatokra” - enyhül a diákok elnyomása. A kis kórház például a civilizáltság szigete: itt nemcsak a felnőttek viselkednek másképp a növendékekkel, de ök is úgy viszonyulnak egymáshoz, mintha a civil világban lennének. Vannak a mindennapokban is olyan időszakok, amikor még valamiféle önkiteljesitésre is lehetöség adódik, ekkor a növendékek azt csinálják, ami építi őket, ami örömet jelent nekik: ez lehet olvasás, színmüírás, rajzolás, rádió összeszerelése, zenélés, vagy éppen hiányjegyzékek gyüjtése (ez Colalto kedvenc elfoglaltsága). ${ }^{13}$ Említhető még az atlétikai versenyre való

\footnotetext{
${ }^{12}$ A Budában Bébé felidézi a hosszú meneteléseket, amelyek során akadt olyan pillanat, amikor a növendék kiszakadhatott az őt körülvevő valóságból, amikor (a pihenő alkalmával) feltekinthetett az égre: „S ha már egyáltalán látni tudtál egy színt, a világ szétesett, zagyva semmilyenségében ez már valamilyen volt.” Majd Medvére utal Bébé, aki tapasztalta, hogy „az ember lelkét a legteljesebb elnyomásban sem lehet elpusztítani, mert teremt magának egy könyökteret, mozgáslehetőséget, mintegy a létezés új dimenzióját, ahol örökre szabad lesz” (Ottlik 1993, 73).

${ }^{13}$ Medve Pascalt, Schopenhauert, Adyt olvas többek között, de Karinthy Így írtok ti című könyve (ami cím szerint nincs megnevezve a regényben) különösen fontos, nemcsak Medvének, hanem Bébének és Szeredynek is: „erőt adott; szilárd radioaktív magja cselekvő szakadatlansággal sugározta a titkot: hogy az élet mégis nagyszabású dolog" (Ottlik 1995, 271). Beszédes, hogy Schulze ezzel szemben „kicsit félt és undorodott a könyvektől” (Ottlik 1995, 289). Érdemes lenne az Iskolát és a Budát a kései Foucault létezés-esztétikája felől is végiggondolni - ez már szétfeszítené jelen írás kereteit. Megvizsgálhatnánk például, hogy Medvéék növendékkori és későbbi önkiteljesítésre törekvése miként viszonyul ahhoz, amit Foucault többek között A szexualitás története III. részében a római császárkor gondolkodói alapján önkultúrának (önmagunkkal való törődésnek) nevez, ez olyan - pl. az önismerettel kapcsolatos - gyakorlatokat foglal magában, amelyek segítségével megtérhetünk önmagunkhoz, azaz eljuthatunk oda, hogy örömet találunk önmagunkban (Foucault 2001, 43-77). Foucault létezés-esztétikájáról írva Cseke Ákos (Cseke 2017) részletesen kifejti, hogy mit is ért Foucault az önmagunkban talált élvezetről, és foglalkozik Pierre Hadot kritikájával is, aki szerint pusztán önmagunkban nem lelhetünk örömet, az egyetemes, a kozmikus dimenzióval való azonosulásra is szükség van (ahogy ezt pl. a sztoikusok is állították).
} 
felkészülés, illetve az ennek ürügyén nyert szabadidő is. „Megtanultunk élni a tájban és egymagunkban a többiek közt. Eltürtek egy-egy lélegzetvételt" (Ottlik 1995, 275). Évközben leginkább a szünidő közeledése ad reményt nekik: a karácsonyi, húsvéti vagy nyári szabadság alatt rövid ideig civil életet élhetnek. Persze a szabadság gyorsan elszalad, és a legtöbbeknek nagy gyötrelmet jelent újból bevonulni az iskolába; a kórházi tartózkodás betegséggel jár együtt, és bár a gyógyulás után még maradhat néhány napot a növendék, ezt követően minden a megszokott módon folytatódik tovább. Az önkiteljesítő elfoglaltságokat Merényiék bármikor félbeszakíthatják, elveszik Medve és Bébé füzetét is, amelybe együtt írnak és rajzolnak, Colalto gyüjteményét pedig Schulze kobozza el. A civilizáció illúzió, így a civilizáció világát idéző szabadságpillanatok is illuzórikusak, de szükségesek. A Budában Bébé Medvét idézi arról, hogy a civilizációs illúziók - amelyekről Bébé festeni akar: az elegancia, a sportszerüség, a dolgokkal való szembenézés stb. - alapvetően fontosak a túléléshez: „Igaz, illúziók! Tartsuk fenn őket, ameddig bírjuk! Ezeknek az illúzióknak a morzsáiból tudtunk megélni három illúziótlan éven át” (Ottlik 1993, 105).

Az Iskolában olyan „világszerkezet” tárul fel, amelyben valahogy mégis a helyére kerülnek a dolgok - de sosem úgy, ahogy az ember elképzelné. A sár és a hó sokat elemzett motívumai ${ }^{14}$ ezt az egyensúlyt fejezik ki: a sár, tehát a megpróbáltatás, a reménytelenség, az üresség időszakát lezáró sürü havazás a reményt jelenti valamiképpen a növendéknek, azt, hogy az élet nem csak parancsszavakból, sárban fetrengésből és állandó küzdelemből, készenlétből áll. A havazás következtében egy időre ténylegesen kissé könnyebbé, nyugodtabbá válik az élet az iskolában. ${ }^{15} \mathrm{~A}$,,világ hideg iszonyata” és az „ólomszürke ég" éppúgy jellemzik a világrendet, mint az, hogy Medvét a fogdában hirtelen békesség tölti el, vagy hogy megtörténik mindaz, ami lehetetlennek tünt, Schulzét negyedéves korukban elhelyezik, aztán váratlanul Merényiék is megbuknak (Ottlik 1995, 137, 207, 238). Merényiék ugyan meggyengültek, de bukásukra, eltávolításukra mégsem számított senki: a történtekről még Bébé is - aki cseppet sem sajnálja őket - úgy gondolkodik, hogy talán valami másnak kellett

\footnotetext{
${ }^{14}$ A motívumok értelmezéséről lásd pl. Balassa 1982, 407-412. „Egész müvészetének keretessége, rejtett ciklikussága fejeződik ki abban, ahogyan az egyes müvekben az elemeket (sár, hó, köd) azonos vagy hasonló értelemben használja" - írja Balassa és emlékeztet arra, hogy A Drugeth-legenda címü (elöször 1939-ben, a Nyugatban megjelent) elbeszélésben ,a hó lehullása szinte szövegszerủen megegyező funkciót tölt be az Iskola ... híres, már-már eposzi, egyben kegyelmi hóesésével” (Balassa 1982, 409). Vö. Ottlik 1994b, 113-132.

${ }^{15}$ A hóesés miatt elmarad a gyakorlat, az osztályteremben a fiúk krumplit sütnek, Bébé akkor kezd közeledni Medvéhez - látszólag indokolatlanul kölcsönadja neki a Bounty fedélzetén-t amikor elöször éli át ezt az élményt (Ottlik 1995, 220-223).
} 
volna történnie velük, bár nem tudja, minek. Nem sokkal a klikk bukása előtt a másságának jelét (a t alakú forradást) ${ }^{16}$ az arcán viselő Medve a párbaj során megjelöli Merényi arcát (Ottlik 1995, 330). A sérthetetlennek tartott növendéken is lehet sebet ejteni: ez mintegy elöre jelzi uralmának végét és a természetes erkölcsi rend helyreállását, azt, hogy a félelemmel teli Merényi-korszakot hamarosan felváltja a Medve és társai által örzött nyugalom időszaka. ${ }^{17}$

A regénynek lehet egy keresztény olvasata, a kegyetlen rendben megtörténő nem várt, felemelö, reményteli események az isteni kegyelem megnyilvánulásaiként is felfoghatók. ${ }^{18} \mathrm{~A}$ müben meghatározó szerepet kap a protestánsok számára különösen fontos „Non est volentis” kezdetü újszövetségi részlet (Pál apostol levele a Rómabelieknek, 9, 16) ${ }^{19}$, amelyben Szent Pál arra hívja fel a figyelmet, hogy Isten könyörülete, kegyelme független az emberi akarattól, erőlködéstől. Mind Medve, mind Bébé protestánsok, és utóbbi olykor bizonytalan megjegyzéseket tesz valamiféle Isteni Rend létezésével kapcsolatban, Medve pedig, amikor újoncként úgy érzi, hogy senkihez sem fordulhat, Jézust képzeli el magának, ,aki magyarázkodás nélkül is érti őt” (Ottlik 1995, 205). Medve fekete kézlenyomata értelmezhető a Merényiék bukásához vezető isteni kegyelem jeleként is - a növendékeknek a tenyérnyom a változatlanságot jelenti sok évig, aztán nem várt események történnek - a szövegben említett „mene tekel” ószövetségi utalás. ${ }^{20}$ Medve számára az erkölcsileg természetes

${ }^{16} \mathrm{~A}$ Medve bal arcán található kis t alakú forradás a szökése során szerzett, elfertőződött seb következménye.

${ }^{17}$ Radnóti Sándor 1996-ban az utolsó ép regényként utalt az Iskolára, és megjegyzi, hogy a müben: „Minden magatartás erkölcsi mérlegen méretik. Nagyjából világosan a helyére kerül minden" (Angyalosi et al. 2001, 312).

${ }^{18}$ Merényiék bukásán kívül például Medve említett békessége a fogdában. Amikor feldagad az arca, Medvét a halál gondolata megnyugvással tölti el, de nem a halál, hanem a civilizáció szigeteként felfogható kórház vár rá. Erről a Budában: „Amit sült bolondságnak tartottál volna, megérted az istenek csoda-dolgát: hogy ahonnét semmi módon nincs szabadulás, kiszabadít egy Zufall, a léggömbbé dagadt fél arcod ostoba véletlensége" (Ottlik 1993, 60).

${ }^{19}$ A Szent Páltól vett idézet megjelenik az Első rész 1. fejezetének címében (,,Non est volentis”), a Károli-féle fordítás részlete pedig a Harmadik rész címe: ,, Sem azé, aki fut”. Az 1. fejezet az idézet latin változatával kezdődik, ami egy régi kőszegi ház felirata és Medve Gábor kéziratának kezdő sora.

${ }^{20}$ Dániel könyve, 5. rész: Dániel megfejti a Belsazár király falán lévő írást, amely szerint Isten véget vet a király országlásának. Lásd erről: Szegedy-Maszák 1994, 128-129. Szegedy-Maszák Mihály feltárja a regény kereszténységgel kapcsolatba hozható részeit, nemcsak a fent említettekről ír, hanem például Medvének a kenyérről kifejtett gondolatait Mózes V. könyvének nyolcadik részével állítja párhuzamba. A kérdéssel foglalkozó részek a könyvben: Szegedy-Maszák 1994, 99-102, 106-108, 120-121, 128-132. Szegedy-Maszák azonban nem hangsúlyozza, hogy 
nem csupán a civilizációs normákat jelenti, ennél szigorúbb elvárásai vannak önmagával szemben, a felebaráti szeretet etikáját követi. Persze ennek megfelelni Medvének is csak tökéletlenül sikerül: olykor gőgösnek, igazságtalannak (lásd például a Bébével kapcsolatos viselkedését, amikor Merényiék elveszik tőle a közös füzetüket), indulatosnak mutatkozik, és az iskolában - újonckori próbálkozásait leszámítva - nem a ,gyengék védelmezője”. ${ }^{21}$ Medve a Merényikorszakban ugyan nyíltan nem véd meg másokat, de önkéntelen reakcióival szakadatlanul az iskola hivatalos rendjének és a diákklikk tetteinek elfogadhatatlanságát állítja. Magatartása összehasonlíthatatlanul keresztényibb, mint a vallási szokásokat betartó, az elvárt normákat felmondó, de „hideg”, szeretetre, barátságra képtelen Tóth Tiboré (azonban, ha beszélünk isteni kegyelemről, ez mégis Tóth tettén keresztül nyilvánul meg). A regény elején a társára „tartózkodó hüvösséggel” néző Tóth Tibor a keresztény etika alapvető elvét idézi (,„Szeresd felebarátodat mint tenmagadat"), aztán kiderül, hogy Tóth senkit nem szeret úgy, mint önmagát (Ottlik 1995, 24). A regény végén Medve 1942-ben született írását olvashatjuk, amelyben a „tízezer lelkü”, olykor nem a legjobb lelkét megmutató Medve arról elmélkedik, hogy a felszínen elszakitott emberek az érzékelésen túli „nagyobb valóságban” folytonosan összefüggenek egymással, és az önmegértés, ami „magányunk közös centruma” felé haladást jelenti, a másikhoz való közelkerülés lehetőségét is hordozza (Ottlik 1995, 357-358). Medve önszeretete és így a felebaráti szeretete is tökéletlen, de a szeretet mégis belsővé vált életelv a számára és nem egy üres frázis, mint Tóth esetében: „Úgy szeretem felebarátaimat, mint önmagamat. Ugyanazzal a fajta szeretettel. Nem jobban. Tehetetlenül, közönyösen, megmásíthatatlanul" (Ottlik 1995, 357). A kéziratát az említett Szent Pál-i idézettel kezdő Medve gondolataiból, megnyilvánulásaiból nem az következik, hogy az éppen adottat minden esetben el kell fogadni, és elég önmagunkat az isteni kegyelemre bízni. Szegedy-Maszák

Medve a felebaráti szeretet (ha ezt némileg sajátosan is értelmezi) gyakorlati megvalósítására törekszik, az ő gyakorlati kereszténysége akkor válik igazán egyértelmủvé, ha szembeállítjuk Tóth Tibor „elméleti” kereszténységével.

${ }^{21}$ A gyengék megvédelmezését az adott rendben képmutatásként értelmezik a növendékek (Ottlik 1995, 322). Medve újoncként kísérletet tesz Merényiék egyik áldozatának megvédelmezésére, de aztán feltehetően megérti, hogy mindig fellépni a másokat érő kisebb-nagyobb sérelmekkel szemben az adott körülmények között lehetetlenné tenné az életet (hiszen ezt Merényiék mindig durván megtorolnák). Viszont a hozzá közel álló Bébé által elkövetett kisebb kegyetlenségek dühöt váltanak ki belöle, és többször szembesíti Bébét cselekedetei problematikusságával, ahogy Merényiék korszaka után - nyilvánvalóvá téve, hogy erkölcsi értelemben is új időszak kezdődik - védelmébe veszi Tóth Tibort. 
Mihály kiemeli, hogy a regény végén egyszerre van jelen kétféle szemlélet: Medve a világhoz való aktív, cselekvő hozzáállás szükségességét hangsúlyozza (,,a világhoz nem alkalmazkodni kell, hanem csinálni”), Bébé pedig azt érzi, hogy „mégis minden csodálatosan jól van, ahogy van”, és ez a két, egyaránt érvényesnek bemutatott magatartás (a lázadás és a tudomásulvétel) a könyvben végig felesel egymással, egyértelmü végkicsengésről sem beszélhetünk, ami gyengíti a mü példázatszerüségét (Ottlik 1995, 357, 362; Szegedy-Maszák 1994, 102). Nem mondhatjuk azt ugyanakkor, hogy a regényben egyértelmúen Medve képviseli az egyik, Bébé a másik szemléletet. Az inkább alkalmazkodó Bébé akarja rávenni Medvét a Merényiékkel szembeni fellépésre. Medve viselkedését pedig egyszerre jellemzi az aktivitás és a megváltoztathatatlan (vagy legalábbis számára annak tủnő) dolgokba való belenyugvás, pontosabban az isteni könyörületre hagyatkozás („Non est volentis”). Medve nem látja értelmét Bébé felvetésének, talán azért, mert még elég erősnek gondolja Merényiéket, vagy úgy véli, végzősként nem érdemes belebocsátkozniuk egy bizonytalan kimenetelü küzdelembe, amely Öttevényi sorsára juttathatja őket. Ugyanakkor az, hogy Medve felidézi a kőszegi vár védőinek győzelmét a török túlerővel szemben („Háromszázezer török táborozott itt”), utalás lehet arra, hogy bár ő nem tartja indokoltnak adott helyzetben a Merényiék elleni nyílt harcot, bizonyos küzdelmeket esélytelenség esetén is fel kell vállalni, a küzdelem kimenetele úgysem az emberi törekvéseken múlik. ${ }^{22} \mathrm{Az}$, hogy a hatalmas török seregnek semmi nyoma nem maradt (Ottlik 1995, 333), azt is kifejezheti, hogy bármiféle óriásinak tünö emberi hatalom csupán időlegesen áll fenn. ${ }^{23}$ És valóban, összeesküvés nélkül is hamarosan véget ér Merényiék uralma. Öttevényi tettének értelmetlenségét teszi nyilvánvalóvá Medve, amikor kéziratában arról ír, hogy nem lehet bevonszolni „az igazság nehézágyúit” a törékeny szerkezetü emberi társadalmakba. Medve ezt a megállapítást végül mégis kihúzza a szövegböl, talán azt jelezve ezzel, hogy más szempontból viszont az értéket felmutató, de kudarcba fulladó tetteket mégsem tarthatjuk hiábavalónak (Ottlik 1995, 180). ${ }^{24}$

\footnotetext{
${ }^{22}$ A várvédők látszólag értelmetlen harcot folytattak, valójában az ellenállást elengedhetetlennek érezhették, hiszen a városukat és a „világrészüket” védték (Ottlik 1995, 332-333).

${ }^{23}$ Lásd ehhez még a mohácsi csata négyszázadik évfordulója kapcsán megfogalmazott, a birodalmak bukásáról szóló gondolatokat: Ottlik 1995, 355.

${ }^{24} \mathrm{Az}$ alapvető értékek védelméért vívott küzdelem vereséggel is végződhet, de az ilyen vereség mindig bizonyos értékek felmutatásának győzelme is. Medve újonckori „vereségei” is az igazságosság, a bátorság értékeit mutatták fel, ahogy Öttevényi is hasonló erényekről tett tanúbizonyságot, sőt, a megalázott, megvert és a többiek elé kiállított Öttevényi akár a megfeszített Jézus szenvedéseit is eszünkbe juttathatja.
} 
A Budában olvashatunk arról, hogy Medve a föreáliskolában már indokoltnak látja az aktív fellépést, verekedést provokál ki, egyedül nekimegy az egész B osztálynak: ha esetleg közülük valakik hatalmi klikket akarnának kialakítani, tudják, hogy ellenállásba fognak ütközni, persze hamar kiderül, hogy a B-sek egyáltalán nem veszélyesek (Ottlik 1993, 138-141). Itt esik szó Medvének a sérelmekkel, illetve a sérelemokozóval szemben tanúsítandó viselkedéssel kapcsolatos „filozófiájáról”, amelyből kiderül - csakúgy, mint az Iskola már idézett részeiből -, hogy Medve sajátosan értelmezi a jézusi szereteteszményt. Medve alapvető fontosságúnak látja a saját méltóságának megvédelmezésére törekvést (ami persze valamiképp általában az emberi méltóságért való kiállás is), ezért annak, aki megüti az arca egyik felét, nem fogja odatartani a másikat, de persze nem is a „szemet szemért” elvet vallja. „Elmélete” szerint mindig vissza kell rúgni (ezzel jelezve az agresszornak, hogy nem mindenki veti alá magát a hatalmának, ez ugyan vezethet az ellenálló teljes megsemmisítéséhez, de ha ez nem következik be, akkor az agresszor tartani fog tőle, és inkább elkerüli), továbbá mindent meg kell tennünk annak érdekében, hogy megszeressük azokat az ellenségeinket, akikkel nem birunk, ilyen módon ártalmatlanná tesszük őket (Ottlik 1993, 139).

A kegyetlenné vált katonaiskola tapasztalatai egy életre meghatározzák az egykori növendékek világfelfogását. Az átélt nehézségek megtanították őket például arra, hogy értékeljenek olyan egyszerü dolgokat, amelyeknek mások nem tulajdonítanak nagy jelentőséget (a „,szabadság enyhe mámorát” érzi Bébé, mert a strandon két lépcső közül azt választhatja, amelyiket akarja, Ottlik 1995, 15). Megtanulták, hogy „gyáva csürhe” vagyunk, az emberek általában - kivételek mindig akadnak - alkalmazkodnak az éppen adotthoz. Megérthették továbbá, hogy az emberek életét, szabadságát, személyiségét nem tisztelö kegyetlen rendszer a „Drághok" (akiket a karrierjükön kívül más nem érdekel) és a ,Matejek” (akik mindig az erösek, a hatalmasok kegyeibe akarnak férkőzni) nélkül nem müködne. Az alreált „túlélő” növendékek a későbbiekben segítik egymást (ezt az 1944-es epizód illusztrálja az Iskolában), hiszen olyan kötelék alakult ki köztük, ,ami talán kevesebb a barátságnál, és több a szerelemnél”, de persze azt is tudják, hogy „egy ponton túl” az ember egyedül vívja a mérkőzését, és senkitől nem kaphat segítséget (Ottlik 1995, 160-161). Jaks, aki gyerekként nem állt ki Öttevényiért, Szeredyért 1944-ben vállalja a kockázatot. Mintha ez a jelenet arra utalna, hogy a durva és erkölcstelen rendben való gyerekkori közremüködésük tapasztalatai sajátos erkölcsi tartást alakítottak ki az egykori növendékben: felnőttként megpróbálnak nem a ,gyáva csürhéhez” tartozni, 
ami egy történelmileg nehéz időszakban akár azt is megkívánja az embertől, hogy a saját biztonságát kockáztassa egy társa életének megmentéséért (Ottlik 1995, 157-161). ${ }^{25}$ Medve is kénytelen elismerni, hogy az emberek időnként nem „gyáva csürheként” viselkednek: az 1956-os forradalom nagy hatással van rá, úgy tünik neki, mintha mégis Petőfinek lenne igaza (legalábbis időlegesen). ${ }^{26}$

Az alreáliskolai időszak talán legfontosabb tapasztalata azonban Bébé és társai számára az volt - ez kiderül a Budából -, hogy ráébredtek: a civilizáció csupán illúzió, a civilizált körülmények és magatartásmódok nem megváltoztathatatlan adottságok, a civilizált rend törékenysége miatt ezek bármikor rövidebb vagy hosszabb időre, a társadalom bizonyos szegmenseiben vagy kiterjedtebb módon - felszámolódhatnak. Gyerekkorukban megtörtént velük az, amiről úgy gondolták, hogy őket nem érintheti, esetleg csak másokat (ezért egy életre kétség támadt bennük „elörejelzésük” megbízhatóságával kapcsolatban): „Elhurcoltak megláncolva gályarabnak. Levágva a fejed-lábad. Zürzavar, és ez is esik szét. (Evezel, evezel)" (Ottlik 1993, 34). ${ }^{27}$ Bébéék tudják, hogy az elképzelhetetlen valósággá válhat: a civilizált emberi rendből bármikor átkerülhetünk a kegyetlenség rendjébe, ugyanakkor a „világ szerkezetéből” az is következik, hogy a megváltoztathatatlannak tünő rossz akár egy pillanat alatt semmivé válhat.

\footnotetext{
${ }^{25}$ Azt nem tudjuk meg az Iskolából, hogy milyen emberekké válnak Merényiék, illetve azok, akik kevésbé szenvedtek a klikk uralmától (pl. Drágh vagy a külső kör tagjai). Csupán a külső körhöz tartozó Halász Péter életét ismerheti meg az olvasó az Iskola előtt megjelent Hajnali háztetőkből. A felnőtt Halászra az erkölcsi tartás a legkevésbé sem jellemző: „Halász Pétert gyatra anyagból faragta a természet; enyhe szó, ha semmirekellőnek, léhűtőnek nevezi őt a világ" (Ottlik 1994c, 36).

${ }^{26}$ Medve korábban vitában állt Petőfivel, hiszen ,,mindenkinek drágább a rongy élete, mint a haza becsülete - vagy mint bármi más ily elvont, absztrakt akármije” (Ottlik 1993, 273). Megtudjuk azt is, hogy Medve 56-ban megsebesül a Kossuth téri sortüzben (Ottlik 1993, 236, 271-278). N. Pál József rámutat a Továbbélők (amelyben a „tudás ólma” még nem nehezedett a szereplökre) és az Iskola világképét összehasonlítva, hogy az Iskola világképét mindaz formálta, amit Ottlik 1948 után megtapasztalt az országban, főként a forradalom, majd annak eltiprása (N. Pál 2000). Kelecsényi László megállapítja: „Nem túl merész feltételezés azt hinni, hogy az 1956-os forradalom és az azt követő rövid életü szellemi pezsdülés váltotta ki az egyszer félretett téma újabb, immár végleges megmunkálásának vágyát” (Kelecsényi 2013, 107).

${ }^{27}$ Korda Eszter a Budát elemezve rámutat, hogy a regényben a rabság és a szabadság ellentéte a „szereplő énnel” és a „néző énnel” hozható összefüggésbe: ,,a szereplő rab, a néző pedig szabad - kívülálló volta miatt” (Korda 2005, 174). A gályarab motívum pedig „minden olyan léthelyzetre vonatkozik, amelyben a kényszer és a monoton változatlanság megakadályozza a néző létet, azaz elnyomja a személyiséget” (Korda 2005, 174).
} 


\section{A kegyetlenné vált felügyeleti intézmény és a kegyetlenség államának erőszakintézménye közötti hasonlóságok és különbségek Ottlik és Kertész regényeiben}

Margócsy István találó megállapítása szerint Ottlik és Kertész is „,világnézeti" író, azaz írásaikban mindketten a világ teljességét próbálják megjeleníteni és ,a társadalmi-hatalmi viszonyok radikális emberellenességét” természetesnek véve az ennek megfeleltethető beszédmódot keresik, illetve az egyéniség szempontjából néznek az egyéniségellenes világra (Margócsy 2002, 206, 209). Ottlik és Kertész világlátása persze alapvetően különbözik, Margócsy szembeállítja egymással az ottliki „minden megvan” alapállást a kertészi „,minden nincs meg" szemlélettel (Margócsy 2002, 210). Ottliknál az egyén elidegenedettsége leküzdhetö: „Ottlik világa rendezett világ, amelyben ugyan aktuálisan elkeserítő rendetlenség uralkodik, de mégis: e világ a szabadság világa, melyben, minden szenvedés és anomália ellenére, alapjában legalábbis elképzelhető vagy egyegy pillanatra megélhető, hogy minden jól van" (Margócsy 2002, 207). Ezzel szemben Kertész katasztrófaközpontú és szabadságnélküli világában ilyesmiről nincs szó, műveiben az egyén mindig radikálisan egyedül áll, és önmagával sem harmonikusan azonos (Margócsy 2002, 206-208). ${ }^{28}$

Nézzük meg a teljesség igénye nélkül, hogy milyen hasonlóságokat és eltéréseket találhatunk egy, a kegyetlenség rendjévé vált felügyeleti intézmény és a kegyetlenség állama által a rendszer ellenségeinek rabszolgasorban tartására, illetve megsemmisítésére létrehozott intézmény között (a következőkben a náci koncentrációs táborok jellegzetességeire utalok). Ennek feltárásához érdemes összevetni az Iskolát és Kertész Imre Sorstalanságát. ${ }^{29}$ Amíg a civilizált állami-társadalmi rendben a kegyetlenné vált felügyeleti intézmény patologikus jelenség, addig a kegyetlenség modern államai célzatosan a felügyeleti

\footnotetext{
${ }^{28}$ Margócsy megállapításai általában érvényesek a két alkotó világszemléletére, de tanulmányában (Margócsy 2002) főként Kertész két kisebb írását, Az angol lobogót és a Jegyzőkönyvet veti össze Ottlik Iskolájával és Minden megvan címü elbeszélésével. Horkay Hörcher Ferenc Kertész Gályanaplója kapcsán megjegyzi: „A ráció munkája, amely által feltárul az ember végzetes és végső esendősége és esettsége, $\mathrm{s}$ a ráció tehetetlensége is e végső esendőség vonatkozásában, egyben valamifajta győzelem is ezen esettség helyzete fölött” (Horkay Hörcher 1999).

${ }^{29}$ Sümegi István úgy véli, hogy az Iskolában bemutatott „,nevelöintézet sokkal inkább emlékeztet Kertész Imre Sorstalanságának világára, Buchenwaldra, mint egy szigorú, poroszos intézetre”, és emlékeztet arra, hogy Vas Istvánnak, az Iskola egyik első olvasójának is a „munkatábori regény” jutott eszébe a műről lehetséges viszonyítási pontként (Sümegi 2006, 193). Sümegi felsorol néhány párhuzamot a két könyv között, a következőkben ennél részletesebben tekintem át témám szempontjából - a hasonlóságokat és különbségeket.
} 
struktúrákat is alkalmazó erőszaktereket alakítanak ki. Az első esetben tehát a felügyeleti intézmény célja morálisan elfogadható, de eltorzult müködése morálisan kifogásolható viszonyokat eredményez, a második esetben viszont már eleve morálisan elfogadhatatlan célból hozzák létre az intézményt. A két mü összehasonlításának alapját témánk vonatkozásában nem önmagában az adja, hogy a katonai iskolában és a koncentrációs táborban is megtalálhatók a felügyeleti hatalom jellegzetességei (az alreáliskola egy iskola és egy kaszárnya keverékeként írható le, a koncentrációs tábor pedig a börtön és a kaszárnya ${ }^{30}$ némely sajátosságait ötvözi), hanem az, hogy az Iskolában egy eltorzult müködésű felügyeleti rendet mutat be Ottlik. A felnőttek támogatásával fenntartott Merényi-diktatúra miatt a felügyeleti intézményben kialakuló állapot párhuzamba állítható a koncentrációs táborokra jellemző totális hatalommal és kiszolgáltatottsággal, de értelemszerúen számos tekintetben eltér egymástól egy ilyen iskola és a koncentrációs tábor világa.

Bébé és társai az elképzelhetetlen valóra válásaként élik meg azt, ami velük történik az iskolában, azok az emberek azonban, akik származásuk miatt vagy egyéb okokból ártatlanul koncentrációs táborba kerültek, nemcsak képletesen, hanem ténylegesen is a gályarabok sorsára jutottak, hacsak nem pusztították el őket rögtön. A Sorstalanságban a tizennégy éves Köves csupán azért kerüli el a gázkamrát, mert idősebbnek mondja magát a szelektáláson (Kertész 2002a, 110). Kövesnek, Medve Gáborhoz vagy Both Benedekhez hasonlóan rá kell ébrednie, hogy egy olyan világba került, amelyben az a természetes, amit ő addig nem tekintett annak, csakhogy ez nem egy nevelési célból fenntartott, de embertelen módon müködö felügyeleti intézmény, hanem a felügyeleti rend elemeit felhasználó koncentrációs tábor. Ahogy a még szinte teljesen üres épületben a katonaiskola újoncainak a parancsolgató zsákvászon egyenruhás, kék sapkás felsőbbéves fiú ,furcsa jelenségnek” tünik (Ottlik 1995, 21), úgy Kövesnek eszébe sem jut, hogy bármi köze lehetne az auschwitzi pályaudvaron látott ,fegyencekhez” (Kertész 2002a, 99). Az újoncok hamar rájönnek, hogy az iskolában ők vannak a hierarchia legalján és jobb, ha a kapott parancsokat teljesítik. Az érkezés után nem telik el sok idő, amikor Kövesnek is szembesülnie kell azzal, hogy öt és társait a pályaudvaron látott „fegyencekhez" hasonlóvá alakították. Az alreáliskola újoncai először az addig megszokottak alapján itélik meg mindazt, ami velük történik, majd rájönnek, hogy

\footnotetext{
${ }^{30}$ Primo Levi megállapítja: „Azt hiszem [...] nyilvánvaló, hogy a lágervilág [...] nem volt egyéb a német katonai módszerek egyik változatánál, alkalmazásánál”, és a foglyok seregét a hadsereg dicstelen másának, karikatúrájának tekinthetjük (Levi 1990, 146).
} 
ennek az iskolának az általuk korábban ismertekhez nem sok köze van, és úgy érzik, hogy „minden összezavarodott” (Ottlik 1995, 62). A Sorstalanságban Köves - társainak többségéhez hasonlóan - akkor is a megtanult civilizációs sémáknak megfelelöen gondolkodik és viselkedik (engedelmesség, a hivatalos személy tisztelete, bizalom az okiratokban, becsületesség), amikor ezek már csupán azt segítik elö, hogy Auschwitzba kerüljön, de még ott sem ébred rá egy darabig, hogy már nincs a civilizáció világában (többek között a civilizációs külsőségek, a rendezettség miatt, a futballpálya, a veteményeskert látványa is megtéveszti öt, a civilizáció itt csupán ,álca”, Kertész 2002a, 114-115). A visszaemlékezésekből tudjuk, hogy sok, Auschwitzba deportált ember egész egyszerüen nem volt képes elhinni, hogy a nácik meggyilkolhatják őket, ha hallottak is valamit a „halálgyárakról”, úgy vélték, hogy az ezekről szóló hírek csupán alaptalan mendemondák. A náci Németországban nyíltan félresöpörtek számos alapvető civilizációs normát, de a tömeges emberirtás tényét még a náci vezetők is titkolni próbálták. Ottlik regényében is álcaként szolgálnak a civilizációs külsőségek: az alreáliskola müködtetői a külvilág felé egy civilizált intézmény képét igyekeznek mutatni. A civilizációs külsőségekkel leplezett kegyetlenségre utal az Iskolának a tanulmány I. részében már említett jelenete, amelyben Formes - aki nem sokkal később Merényi áldozatává válik - apját mosolyogva nyugtatja meg egy örnagy (Ottlik 1995, 53-55). A Sorstalanságban - itt nem az iskolai erőszakot próbálják leplezni, hanem emberek tömeges elpusztítását - hasonló történetet találhatunk: a ,Szakértö" megnyugszik a kifogástalan modorú német tiszt „korrekt és reális” tájékoztatása után. A „Szakérto”” aztán Auschwitzba kerül, ahol a szelektáláson alkalmatlannak minősítik, tehát azonnali halál vár rá (Kertész 2002a, 88, 113).

Az Ottlik által leírt iskolában embert próbálóak a körülmények, de a növendékek például rendesen kapnak enni (ha nem is mindig a kedvükre való ételeket ehetik), amíg a koncentrációs táborok rabjai csak éppen annyi ételt kaptak, amelyről fogvatartóik azt gondolták, hogy éppen elég munkaképességük megőrzéséhez. A koncentrációs táborban az alávetettek közötti harcot nemcsak eltürték vagy támogatták, hanem a tábor rendjét kifejezetten úgy alkották meg, hogy a rabok egymással szembeni kegyetlenségét elösegitsék. Felfüggesztették a foglyok esetében a civilizált viselkedésmódok, szokások (amelyek Nyugaton az újkori fejlődés során alakultak ki, lásd Elias mủvét: Elias, 2004) gyakorlásának lehetőségét. A természetes intéznivalókkal, az étkezéssel, az emberek közti érintkezéssel kapcsolatos szokások civilizáció előtti szintre estek vissza. A foglyok élete folyamatosan veszélyben volt a nehéz fizikai munka, a felügyelők erőszakossága, a kevés étel, a betegségek miatt. A táborok kitalálói- 
nak kifejezetten céljuk volt az is, hogy olyan állapotot teremtsenek, amelyekben a foglyoknak szembesülniük kell saját erkölcsi lealacsonyodásukkal, ezért müködtették többek között a fogolyfunkcionáriusok rendszerét is: a kápók, akik egyszerre voltak áldozatok és tettesek, a kegyetlenségben sokszor túltettek az SS-katonákon. A foglyok közül sokan vélhették úgy, hogy az önfenntartáshoz való joguk érvényesítése felülírja a civilizált rendben elsajátított alapvető morális normákat. A foglyok erkölcsi lealacsonyodására, a mindenki háborúja mindenki ellen állapothoz hasonló viszonyokra több visszaemlékező is utal (Levi 1994, 116; Frank1 2013, 22). A harc eszközei változatosak voltak: a lopás, a másik kihasználása, az ügyeskedés növelte a foglyok túlélési esélyeit. A felügyelet a foglyok egymás közti küzdelmét nem akadályozta, sőt, inkább elősegítette: egyrészt a már említett fogolyfunkcionárius-rendszer révén, másrészt a tábori rend úgy volt kitalálva, hogy akik minden szabályt betartottak és nem tudták valahogyan kiegészíteni az ellátásukat, általában pár hónap alatt meghaltak (Levi 1994, 113). E struktúra a foglyok morális fölényének megsemmisítésére irányult: a nácik rámutathattak a kollaboráló, vagy túlélésük miatt alapvető normákat megszegő rabok erkölcstelenségére, illetve a rabok értéktelenségérzését ezzel is erősítették. Persze még a koncentrációs táborban is voltak lázadók, akik számára ez a biztos halált jelentette. A nyílt lázadókon túl akadtak emberek, akik törödtek másokkal, és nem csak a saját érdekeiket nézték. A Sorstalanságban ilyen Bohús, vagy Citrom Bandi, aki ugyan egy idő után elkerüli a „muzulmán”-állapotba kerülő Kövest, de aztán ő viszi el (egy másik fogoly segítségével) a Revier sátrához (Kertész 2002a, 220).

A katonaiskolában csak a felügyeleti rendszer múködéséből adódó lealacsonyítás a hivatalos rend része, a domináns diákcsoport terroruralma nem, az, így ez, főként a felnőttek beavatkozásával, bármikor megszüntethető. Továbbá a növendékeknek rendelkezésre állnak az adott rendböl való kilépés különböző lehetőségei: időnként kiszakadnak a romboló közegből (nyugalmasabb pillanatok, szabadságok, kórházi tartózkodás), reményt adhat nekik az is, hogy a tanulmányaik befejeztével véglegesen elhagyhatják az iskolát, illetve akár a szüleiket is meggyőzhetik arról, hogy vegyék ki őket innen, mint ahogy Medve anyja a fiú szökése után hajlana rá, hogy fiát hazavigye, de akkor már Medve maradni akar. A koncentrációs táborban szerencsés esetben a kórházbarakkban tartózkodás hozhatott némileg könnyebb időszakot, persze, ha a rab nem gyógyult megfelelően, akkor a gázkamrában is végezhette. Kövest a zeitzi kórházbarakkban tapasztalt állapotok után elkápráztatja a buchenwaldi kórház berendezési tárgyainak a koncentrációs tábor világától idegen „csaknem kaszárnyai fényüzése”, a paplanos ágy, a csend, és azt hiszi, hogy ez csak egy „tréfa”, 
a szoba valójában leplezett kivégzőhely (Kertész 2002a, 257-258). A foglyok egyetlen reménye az lehetett, hogy egyszer - ki tudja, mikor - felszabadítják a tábort. Az alreáliskolában a növendékek önmegőrzéséhez az idővel kialakuló „barátságok” is hozzájárultak, illetve némi menedéket nyújtottak számukra, ha csak rövid időre is, az önkiteljesítésüket elösegítő foglalatosságok (olvasás, írás, rajzolás, sport stb.). A koncentrációs táborokban is lehettek nyugalmasabb pillanatok, de ha ezek az önmegőrzést (pl. amikor a fogoly felidézte korábbi életének kedves emlékeit, szeretteire gondolt) valamelyest segíthették is, önkiteljesítésről értelemszerüen nem beszélhetünk. Kövesnek a „,koncentrációs táborok boldogságával” kapcsolatos megjegyzése („még ott, a kémények mellett is volt a kínok szünetében valami, ami a boldogsághoz hasonlított") inkább arra utalhat, hogy a koncentrációs tábor az emberi világ részét képezi - amelynek hétköznapjaiban nyugodtabb pillanatok is akadtak - ezért nem távolíthatjuk el magunktól, nem nevezhetjük azt „,pokolnak”. ${ }^{31}$ Az Iskola világképe szerint a sár korszakát (legalábbis egy időre) elfeledteti a havazás, a szenvedést nem várt megnyugvás követheti, és megtörténhet az, amire sokan vágytak, de aminek bekövetkezésére senki sem számított. A Sorstalanságban Kövest, amikor a többi beteggel együtt Buchenwaldba szállítják (Kertész 2002a, 234), békesség tölti el (hasonlóan a feldagadt arcú Medvéhez, aki úgy érzi, hogy talán meg fog halni, Kertész 2002a, 239), aztán a táborban Köves a pocsolyákkal teli földről végül lepedős-paplanos ágyba kerül, és valódi gondoskodásban részesül. Ottliknál a dolgok helyükre kerülése egy olyan világrend tanúbizonysága, amelynek

\footnotetext{
${ }^{31}$ Éppen ezért problémás azonos nevezőre hozni az ottliki „könyöktér szabadságot” és a „koncentrációs táborok boldogságát”, ahogy Nagy Edit teszi (Nagy 2014,7-12). Talán a koncentrációs tábor foglya is teremthetett magának valamiféle „,könyöktér szabadságot”, de a „koncentrációs táborok boldogsága" biztos, hogy nem azokat a pillanatokat jelenti, amikor a fogoly úgy érezte, hogy most emberhez méltó életet él, mert ilyesmiről egy koncentrációs táborban nem lehetett szó (még a buchenwaldi kórházbarakk is csak a zeitzi kórházbarakkhoz képest fényüzö, és az ilyen körülményeket, bánásmódot is „tréfaként” értelmezi Köves). Ezzel ellentétben az Ottlik által leírt katonaiskolában rendszeresen akadnak olyan időszakok, ha rövidek is, amikor a növendék kizárhatja az öt körülvevő világot, amikor nem kell harcolnia önmagáert, amikor azzal foglalkozhat, amivel szeretne. Meghatározó tekintetben mást jelent Bébének az alreáliskola kapcsán megfogalmazott ,idiotikus honvágya” - erről a Budában olvashatunk - és Köves ,honvágya”. Bébé évek múltán tekint vissza az alreáliskolai évekre, ahol a nehézségek mellett megélt felemelő pillanatokat is (sár és hó), de még így is furcsa ez a honvágy (,idiotikus”). A néhány hónapja szabadult Kövesben még erősen élnek a tábori mindennapok emlékei, ezek rohanják meg a késő délutáni órán: Köves úgy tekint a világra, amelyben a koncentrációs táborok, az ember rabszolgasorba vetése, a krematóriumok léte természetes, otthon viszont elvárják tőle, hogy ezt a tudását felejtse el, vagy legalább minősítse „,pokolnak” azt, amit megjárt. Köves azért érez honvágyat a tábor „bizonyos értelemben” „tisztább és egyszerübb” élete után, mert ott minderre (színlelésre, a világ valódi természetének elfedésére) nem volt szükség.
} 
része a kegyelem, Kertész regényében viszont Köves megmenekülése szerencsés véletlenek sorozatának tünik. A Buchenwaldban földön fekvő Köves az „alacsony, szürke és átlátszatlan eget” kémleli, és a meghasadozó felhőzetben támadó fényességet nem a transzcendens - reményt hordozó - megnyilatkozásaként fogja fel: a fényes lyuk látványa a szelektálást végző auschwitzi orvos szemét idézi fel benne (Kertész 2002a, 236). Míg a kegyetlen alreáliskolát kijáró növendékeket az átélt nehézségek megerősítették, mivel olyan tapasztalatokat, emberi kapcsolatokat eredményeztek, amelyek élni segitik őket, addig Köves az emberi kegyetlenség lehető legradikálisabb változatával szembesült kamaszként, élete valójában folytathatatlan, de mégis élni vágyás van benne: „folytatni fogom folytathatatlan életemet” (Kertész 2002a, 333). ${ }^{32}$ Kertész

${ }^{32} \mathrm{~A}$ K. dossziéban Kertész Améry „Weltvertrauen” fogalma kapcsán arról ír, hogy a koncentrációs táborban sem vesztette el a világba vetett bizalmát: ,úgy képzeltem, hogy a felnőtt emberek világának az a kötelessége, hogy engem innen kimentsen és épségben hazajuttasson" (Kertész 2006, 18). Ez persze nehezen egyeztethetö össze azzal a felismeréssel, amit Kertész két oldallal ezelött, A kudarcot idézve említ, miszerint megértette, hogy a számára adott világegyetemben bárhol, bármikor agyonlőhető (Kertész 2006, 16). Nagy Edit az előbbi idézet alapján próbálja értelmezni a Sorstalanságot, és úgy gondolja, hogy Köves a világba vetett bizalmát a koncentrációs táborban is megőrzi, és csak az otthoni rideg, részvétlen viszonyok között veszti el ideiglenesen, de átgondolva az életét, édesanyjához már „újfajta bizakodással” indul (Nagy 2014, 9-10). Ez az értelmezés nehezen fogadható el, kezdve azon, hogy a regényben semmi nyomát nem találjuk annak, hogy a koncentrációs táborból szabadult Kövest éppen az törné össze lelkileg, hogy otthon egy hideg, elutasító világ vár rá (egyébként ez sem igaz teljesen, mert Fleischmannék és Steiner bácsi szeretettel fogadják). Továbbá meglehetősen problémás azt állítani, hogy Köves a koncentrációs táborban is megőrzi a világba vetett bizalmát - a regényben nincs jelen egyértelműen az, amiről Kertész a $K$. dossziéban a saját élete kapcsán beszél -, hiszen Köves, miután megérti a krematóriumok rendeltetését Auschwitzban, a koncentrációs tábor világát tartja természetesnek, és - ahogy ez már többször szóba került - a buchenwaldi kórházi szobát egyfajta leplezett kivégzőhelynek képzeli. Sümegi István rámutat, hogy mind Ottliknál, mind Kertésznél meghatározó fontosságú a „lehetséges-e egyáltalán tovább élni?” kérdése (ezt a kérdést veti fel a Továbbélők és az Iskola között keletkezett két regénytöredék, a Szebek és a Czakó is). Sümegi szerint a két szerző válasza is hasonló: nem elfeledni kell a történteket, hanem beépíteni a személyiségünkbe, világlátásunkba. Ottliknál ez egyértelmü, de Kertész is ilyen gondolatokat fogalmaz meg A holocaust mint kultúra címü esszéjében (Sümegi 2006, 195). A párhuzam azonban nem teljesen találó. Ottlik müveiben a katonaiskolában átélteknek a személyiségbe való beépülése valóban élni segíti az egykori növendékeket, a holokauszt túlélői esetében azonban általában ez nem így működött. Számos, a velük történtekkel szembenéző holokauszt-túlélő lett öngyilkos - köztük írók, akik a civilizációs traumából és saját traumájukból kultúrát teremtettek, pl. az említett Levi és Améry -, de az is sokatmondó, hogy Kertész utolsó regényének, a Felszámolásnak (Kertész 2003) Auschwitzban született szereplője öngyilkosságot követ el. Kertész a holokauszttal mint kultúrával kapcsolatos írásaiban - amelyek nem mentesek az ellentmondásoktól, lásd erről Barcsi 2018, 61-65 -, nem a túlélők továbbélésének kérdését állítja középpontba, hanem kifejti, hogy a nyugati civilizációban élőknek (és másoknak is) alapvető fontosságú lenne a holokauszt tapasztalatából tanulva újrafogalmazni alapvető értékeiket, együttélési normáikat. 
Kaddis a meg nem született gyermekért címü müvében B., az elbeszélö kifejezetten párhuzamba állítja egykori nevelőintézetének müködésmódját - amely, bár csak néhány sajátosságát ismerjük meg, feltehetően kevésbé volt kegyetlen, mint az Ottlik-regény katonaiskolája - és Auschwitz rendjét (Kertész 2002b, 136-139, 146-150). Az elembertelenítö felügyeleti struktúra és a félelmen alapuló „apakultúra” gyerekkori megtapasztalása miatt mondja B. a feleségének, hogy Auschwitz „később csupán azon erények túlhajtásának tünt nekem, melyekre már kora gyermekkorom óta neveltek" (Kertész 2002b, 155).

A kegyetlenné vált felügyeleti rend összevetése a koncentrációs tábor rendjével megmutatta, hogy a koncentrációs táborokat a többletkegyetlenség jelenlétével jellemezhető felügyeleti intézmények radikálisabb változatának tekinthetjük. A történelmi tapasztalatok azt mutatják, hogy az ember a civilizációs fejlődés során létrejött müködésmódokat képes civilizációellenes módon, az alapvető morális normák figyelembevétele nélkül, vagy azokat bizonyos vonatkozásokban kifejezetten érvénytelenné nyilvánítva felhasználni. A civilizált társadalomban müködő, az ottliki katonaiskolához hasonló, kegyetlenné vált, az emberi méltóságot semmibe vevő egykori intézmények valóban Auschwitz elöképeinek tekinthetök, mint ahogy azok a mai intézmények, amelyekben az emberre csupán egy eldobható, pótolható alkatrészként tekintenek, valamiképpen az ilyen bánásmód lehető legradikálisabb változatát, Auschwitz rendjét idézik meg.

\section{Irodalom}

Angyalosi Gergely-Bán Zoltán András-Beck András-Radnóti Sándor. 2001. Irodalmi kvartett. In Az elbeszélés nehézségei: Ottlik olvasókönyv, szerk. Kelecsényi László. Budapest: Holnap.

Balassa Péter. 1982. Ottlik és a hó. Jelenkor 25 (5): 407-412.

Barcsi Tamás. 2017. Változatok a kegyetlenségre. Filozófiai vázlat a civilizáció és az embertelenség néhány kérdéséről I. Nagyerdei Almanach 7 (1): 1-40.

Barcsi Tamás. 2018. A kudarc lehetősége: Kertész Imre müveiről erkölcsfilozófiai szempontból. Partitúra 13 (2): 23-68.

Barcsi Tamás. 2019. Bevezetés a kegyetlenség világába: Civilizáció, felügyeleti hatalom és kegyetlenség Ottlik Géza müveiben. Hungarológiai Közlemények 20 (2): 64-83.

Cseke Ákos. 2017. Élet, öröm: A kései Foucault létezés-esztétikája. Mühely 41 (5-6): 58-64.

Elias, Norbert. 2004. A civilizáció folyamata. Ford. Berényi Gábor. Budapest: Gondolat. 
Foucault, Michel. 2001. A szexualitás története III.: Törödés önmagunkkal. Ford. Sujtó László. Budapest: Atlantisz.

Frankl, Viktor E. 2013. ...mégis mondj igent az életre!: Egy pszichológus megéli a koncentrációs tábort. Ford. Kalocsai Varga Éva. Budapest: JEL.

Horkay Hörcher Ferenc. 1999. Számadás. Élet és Irodalom 43 (44): 14.

Kelecsényi László. 2013. Ottlik Géza életei: A megértés iskolája. Budapest: Fapadoskonyv.hu

Kertész Imre. 2002a. Sorstalanság. Budapest: Magvető.

Kertész Imre. 2002b. Kaddis a meg nem született gyermekért. Budapest: Magvető.

Kertész Imre. 2003. Felszámolás. Budapest: Magvető.

Kertész Imre. 2006. K. dosszié. Budapest: Magvető.

Korda Eszter. 2005. Ecset és toll: Az Ottlik-próza vizuális narrációja. Budapest: Fekete Sas.

Levi, Primo. 1990. Akik odavesztek és akik megmenekültek. Ford. Betlen János. Budapest: Európa.

Levi, Primo. 1994. Ember ez? In Ember ez?: Fegyvernyugvás. Ford. Magyarósi Gizella. Budapest: Európa.

Margócsy István. 2002. „Minden nincs meg”: A megfogalmazás kalandja. In Azértelmezés szükségessége: Tanulmányok kertész Imréröl, szerk. Scheibner Tamás, Szücs Zoltán Gábor. 199-210. Budapest: L’Harmattan.

Nagy Edit. 2014. A világba vetett bizalom és az idiotikus honvágy. Párhuzamok Ottlik Géza és Kertész Imre regényvilágában. Irodalomismeret 3. http://www.irodalomismeret.hu/files/2104_3/nagy_edit.pdf(2019.júl. 10.)

N. Pál József. 2000. „...védeni egy kis várat...”. Kortárs 44 (2): 101-109.

Ottlik Géza. 1993. Buda. Budapest: Európa.

Ottlik Géza. 1994a. Apagyi. In Hajnali háztetők: Minden megvan. 383-388. Budapest: Európa.

Ottlik Géza. 1994b. A Drugeth-legenda. In Hajnali háztetők: Minden megvan. 113-132. Budapest: Európa.

Ottlik Géza. 1994c. Hajnali háztetők. In Hajnali háztetők: Minden megvan. 7-110. Budapest: Európa.

Ottlik Géza. 1995. Iskola a határon. Budapest: Magvető.

Ottlik Géza. 1999. Továbbélők. Pécs: Jelenkor.

Sümegi István. 2006. A boldogság ize: Ottlik Géza történetei. Pécs: Jelenkor.

Szegedy-Maszák Mihály. 1994. Ottlik Géza. Pozsony: Kalligram. 


\section{LITERARY REPRESENTATIONS OF SUPERVISORY ORDER IN OTTLIK GÉZA AND IMRE KERTÉSZ'S NOVELS}

The author as a continuation of his study Introduction into the World of Cruelty: Civilisation, supervisory power and cruelty in Géza Ottlik's works sums up the modes of cruelty found in the novel, and also shows how human order and world order are connected in the world of Géza Ottlik’s novels. He compares Ottlik’s main work with Imre Kertész's Fatelessness, and points out the parallels which can be drawn between a cruel regime of surveillance and a concentration camp, or between the literary representation of them.

Keywords: supervision, civilisation, rebellion, school, concentration camp

\section{KNJIŽEVNI PRIKAZ NADZORNE VLASTI U ROMANIMA GEZE OTLIKA I IMREA KERTESA}

Rad predstavlja nastavak teksta Uvod u svet svireposti: Civilizacija, nadzorna vlast i svirepost u delima Geze Otlika. Dat je pregled različitih načina pobune u romanu Škola na granici te povezanost ljudskog i svetskog poretka u romanima istog autora. Poredi se glavno Otlikovo delo sa romanom Besudbinstvo Imrea Kertesa i ukazuje na paralele između svirepe nadzorne vlasti i koncentracionog logora, odnosno između njihovih književnih prikaza.

Ključne reči: nadzor, civilizacija, pobuna, škola, koncentracioni logor 